\title{
Two Consecutive Acute Coronary Syndrome Patients after Dinitro-Ortho-Cresol Exposure
}

\author{
Dinitro-Ortho-Cresol Maruziyeti Sonrasında Akut Koroner Sendrom Gelişen \\ Ardışık Iki Hasta
}

Ahmet Oğuz Baktır1', Hayrettin Sağlam¹, Bahadır Şarlı', Hüseyin Arınç', Yasemin Doğan'1, Hüseyin Katlandur²

'Clinic of Cardiology, Kayseri Education and Research Hospital, Kayseri, Turkey

2Department of Cardiology, Faculty of Medicine, Mevlana University, Konya, Turkey

\section{ABSTRACT}

Nitrophenols are common components of industrial effluents and have been detected in urban and agricultural waste. Dinitroortho-cresol (DNOC) can easily enter the body through inhalation, ingestion or the skin. Yellow staining is typical in toxications via skin contact. The main toxic effects of DNOC derivatives are due to an increase in cellular metabolism. It acts directly on metabolism by inducing cellular oxidation and inhibiting phosphorylation, leading to the uncoupling of oxidative phosphorylation. Cardiovascular effects appear to be secondary to cellular anoxia. We report here two consecutive patients admitted to the emergency department with an initial diagnosis of toxic exposure to DNOC. Further examination revealed that toxic exposure led to simultaneous acute coronary syndrome.

Keywords: 2,4-dinitrophenol, acute coronary syndrome, toxic exposure to 2, 4-dinitrophenol, DNOC

Received: 04.01.2013 Accepted: 04.02.2013

\section{ÖZET}

Nitrophenoller sıklıkla endüstriyel, kentsel ve tarımsal atıklarda tespit edilmiştir. Dinitro-ortho-cresol (DNOC), solunum, sindirim ya da cilt yoluyla vucuda alınırlar. Temel olarak hücresel metabolizmayı hızlandırarak zehirli etkilerini gösterirler. Oksidatif fosforilasyonun ayrışması, hücresel oksidasyonun artması ve fosforilasyonun baskılanması neticesinde olur. Kardiyovasküler etkileri hücresel anoksiye ikincil olarak oluşur. Makalemizde DNOC maruziyeti sonucunda akut koroner sendromun tetiklendiği düşünülen, ardışık olarak acil servise başvurmuş iki hasta sunulmuştur.

Anahtar Kelimeler: 2, 4-Dinitrofenol, akut koroner sendrom, 2, 4-Dinitrofenol toksik maruziyeti, DNOC

Geliş Tarihi: 04.01.2013 Kabul Tarihi: 04.02.2013

\section{Introduction}

Acute pesticide poisoning is one of the most common causes of fatality. The causes of pesticide poisoning are mostly insecticides, herbicides, and rodenticides. The fatalities caused by pesticides are often due to suicidal intentions (1). However, especially in the spring and summer time, the incidence of poisoning increases unwittingly or due to environmental reasons. Nitrophenols are common components of industrial effluents and have been detected in urban and agricultural waste. They are highly toxic chemicals with six isomeric compounds and are widely utilised in dyes, developers, drugs, indicators, insecticides, and in the preservation of wood (2). 2, 4-Dinitrophenol (DNOC), the most toxic compound, is a yellow, combustible crystalline solid that has a musty odour and has poor solubility in water (2).

Poisoning by inhalation is seen more in agricultural and explosive production workers. As far as we know, most case reports about DNOC poisoning, especially the death reports, mainly concern poisoning through the digestive system, such as conscious intake. Here, we report two patients with the diagnosis of acute coronary syndromes attributed to DNOC poisoning though non-oral contact. 


\section{Case Reports}

\section{Case 1}

A 70-year-old man was admitted to the coronary intensive care unit with the diagnosis of subacute ST elevation myocardial infarction. He had chest pain after performing agricultural spraying on the previous day. Past medical history did not reveal previous coronary artery disease but revealed smoking. Physical examination revealed a pulse rate of 79 beats per minute (bpm), systolic blood pressure of $110 / 75 \mathrm{mmHg}$, respiratory rate of 18 breaths/min, body temperature of $36.9^{\circ} \mathrm{C}$, and no abnormal findings except prominent yellow staining of both hands on admission. Figure 1, a photograph that was taken 3 days after exposure, shows that the yellow staining was still present. ECG showed sinus rhythm, Q waves in anterior leads, and ST elevation indicating subacute anterior myocardial infarction

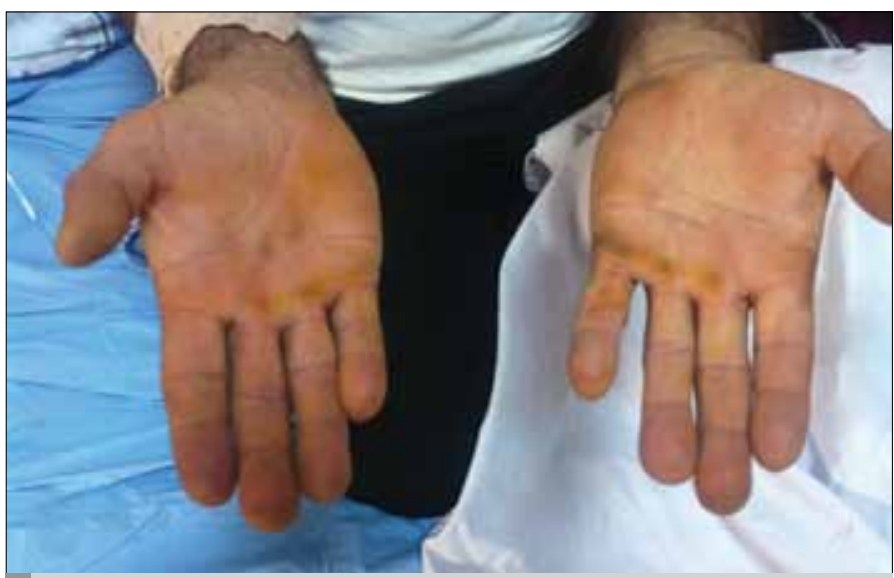

Figure 1. Image taken after 3 days of exposure, which shows the yellow staining of the hands

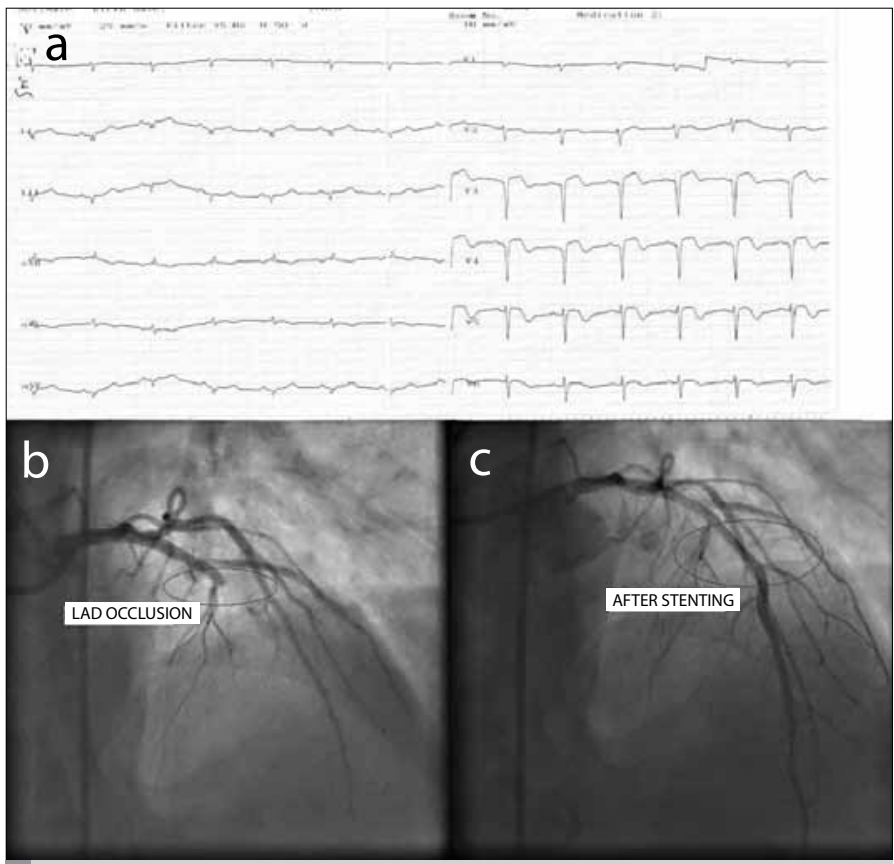

Figure 2a. ECG indicating subacute anterior myocardial infarction. b, c. LAD occlusion and after stenting of the vessel
(Figure 2a). Troponin-l level was 21.19 ng/mL (normal: 0-0.1 ng/mL). Medical treatment including acetylsalicylic acid $300 \mathrm{mg} /$ day, clopidogrel loading dose 600 mg, bisoprolol 2.5 mg/day, atorvastatin 40 $\mathrm{mg} /$ day, and enoxoparin 2x60 mg/day was initiated. Afterwards, the patient was referred for coronary angiography (CAG). On CAG, the circumflex and right coronary artery (RCA) were normal, but the left anterior descending artery (LAD) was occluded after the diagonal branch (Figures 2b, c). Subsequently, direct stenting was performed on two lesions on the LAD. The patient was discharged after 2 days of medical monitoring without any complication.

\section{Case 2}

A 79-year-old man was admitted to the coronary intensive care unit with the diagnosis of non-ST elevation myocardial infarction. He also had chest pain after performing agricultural spraying. Past medical history revealed type 2 diabetes, on oral antidiabetic treatment, with no known coronary artery disease. Physical examination revealed a pulse rate of 75 bpm, systolic blood pressure of 120/80 $\mathrm{mmHg}$, respiratory rate of 20 breaths/min, body temperature of $36.3^{\circ} \mathrm{C}$, and no abnormal findings except yellow staining on both hands as in the first patient. ECG showed atrial fibrillation, and Q waves in V1-V2 leads indicating previous anteroseptal myocardial infarction (Figure 3a). Troponin-I level was $0.28 \mathrm{ng} / \mathrm{mL}$ (normal: 0-0.1 ng/mL). Medical treatment was initiated with acetylsalicylic acid $300 \mathrm{mg} /$ day, clopidogrel loading dose $600 \mathrm{mg}$, bisoprolol 2.5 $\mathrm{mg} /$ day, atorvastatin $40 \mathrm{mg} /$ day, ramipril $2.5 \mathrm{mg} /$ day, and enoxoparin 2x60 mg/day. Subsequently, the patient referred for CAG, which revealed long diffuse $L A D$ stenosis, a subtotally occluded obtuse marginal artery, and subtotally occluded RCA (Figures 3b, c). The patient was referred for coronary artery bypass surgery (CABG) and

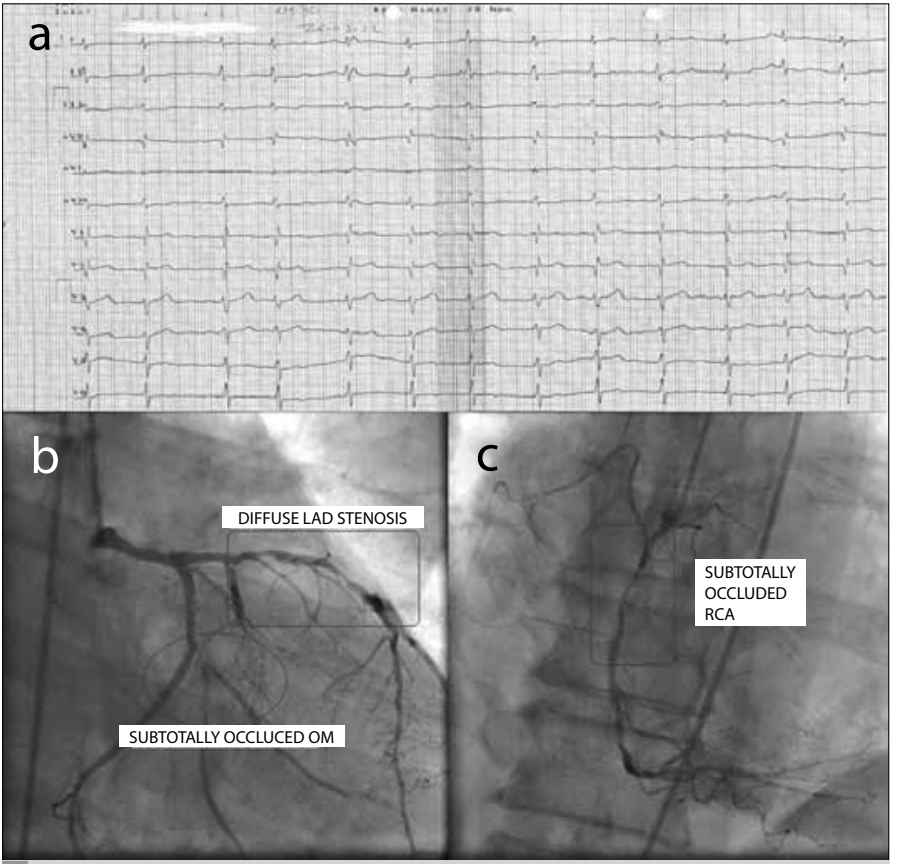

Figure 3a. ECG indicating fibrillation, Q waves in V1-V2 leads indicating previous anteroseptal myocardial infarction. b, c. Long diffuse LAD stenosis, subtotally occluded obtuse margin artery, and subtotally occluded RCA 
treated successfully by CABG. Informed consent were obtained from each patient.

\section{Discussion}

2,4-Dinitrophenol derivatives are widely used herbicides. Therefore, poisoning by DNOC occurs mostly in agricultural workers and sometimes results in death. DNOC toxicity includes acute and chronic effects. DNOC can easily enter the body through inhalation, ingestion or the skin, and is considered to be highly toxic to humans, with a lethal oral dose of $14-43 \mathrm{mg} / \mathrm{kg}$ (3). Yellow staining is typical in toxications via skin contact. Our patients also had this typical prominent yellow staining on the hands and palms on admission due to skin contact with DNOC.

In acute cases, symptoms of DNOC toxicity include restleness, a sensation of heat, flushed skin, sweating, thirst, deep rapid respiration, tachycardia, a severe increase in body temperature, cyanosis leading to collapse, coma and death. The effects are enhanced at high temperatures (4). Long-term oral exposure to DNOC in humans and animals results in the formation of cataracts and skin lesions and has effects on the bone marrow, central nervous system, and cardiovascular system (3). DNOC is readily absorbed after inhalation, ingestion, and especially by skin contact. It is eliminated mainly via the urine. Experimental work in animals and humans has demonstrated that DNOC is a cumulative poison. The elimination half-time varies from species to species and may last as long as 7 days for humans (5)

The main toxic effects of 2,4-dinitrophenol derivatives are due to an increase in cellular metabolism, and this toxic risk increases at high environmental temperature (5). Although the mechanisms are different, DNOC derivatives increase basal cellular metabolism, similar to thyroxin. It acts directly on metabolism by inducing cellular oxidation and inhibiting phosphorylation, leading to the uncoupling of oxidative phosphorylation (6). The electrochemical gradient normally generated by the electron transport chain is harnessed as ATP. DNOC irreversibly bypasses this system, with the result that cells must rely solely on the anaerobic Krebs cycle for energy. In order to meet the energy deficit, energy reserves from adipose tissue are consumed, increasing the basal metabolic rate and leading to the desired effect of weight loss, with the predictable consequence of thermogenesis (7). As a result of this effect, fatty acid oxidation is also abolished (5). Furthermore, DNOC uncouples oxidative phosphorylation, leading to the release of calcium from mitochondrial stores. Raised free intracellular calcium leads to muscle contraction and hyperthermia (8). In our cases, the typical increase in metabolism and temperature was not seen. However, increased intracellular calcium via the uncoupling of oxidative phosphorylation might have triggered coronary vasospasm and plaque rupture. Both patients' coronary angiography revealed underlying coronary atherosclerosis. Increased intracellular calcium might have posed acute insufficiency of already reduced coronary reserve through damaged endothelium. A high fever and profuse sweating are symptoms common to all such patients and are related to the degree of exposure; the critically ill patients die of cardiac arrest in a short time. Because there is no antidote, clearing toxins from the body and maintaining homeostasis by supportive care are equally important.

Cardiovascular effects appear to be secondary to cellular anoxia but do not appear to be consistent with cardinal signs of DNOC exposure in humans. However, elevated pulse rates, tachycardia, and palpitations were observed in several patients. Although the basal metabolic rate was increased, the cardiovascular system was not affected after volunteers ingested $3 \mathrm{mg} / \mathrm{kg} /$ day DNOC for 4 days or 0.92-1.27 mg/kg/day for 5-7 days. Changes in blood pressure and pulse rate were regarded as not significant. A pulse rate of 90 beats per minute (bpm; an insignificant increase over the normal 72 bpm) was observed in a girl who ingested a time-weighted average dose of $2.27 \mathrm{mg} / \mathrm{kg} /$ day DNOC for 11 days for purposes of weight reduction (9). In our cases, although toxic exposure was through skin contact and inhalation, it might not have reached the toxic dosage for classical poisoning symptoms. We were unable to dedect the blood level of DNOC because of a lack of laboratory facility. However, the exact history of exposure (patients brought the box of agricultural pesticide Trifocide $\mathrm{DNOC}^{\circledR}$ ) to DNOC and typical yellow staining led to the diagnosis of DNOC toxicity.

The symptoms of acute poisoning result from the effects on cellular metabolism and include severe thirst, painful colic, diarrhoea, and vomiting. Dyspnoea, cyanosis, tachycardia, and cardiac insufficiency with anginal pain have also been described. Oedema of the fingers and hands has also been observed, possibly suggestive of circulatory dysfunction. Death is due to respiratory or circulatory collapse. Many factors undoubtedly contribute to this collapse, notably hyperpyrexia, dehydration, muscle rigor (due to heat and/ or lactic acid), and occasionally pulmonary oedema (10). Although poisoning led to the serious situation of acute coronary syndrome in our cases, we think that the poisoning was not fatal due to the low dosage but it was probably enough for plaque rupture due to altered cellular metabolism and triggered coronary vasospasm via increased intracellular calcium.

\section{Conclusion}

In our country, DNOC is widely used for agricultural spraying. Especially in the spring and summer time, the high environmental temperature increases the probability of poisoning in agricultural workers. As mentioned in our cases, poisoning may result in acute coronary syndromes that may be life-threatening, even without the typical symptoms

\section{Conflict of Interest}

No conflict of interest was declared by the authors.

Peer-review: Externally peer-reviewed.

\section{Author Contributions}

Concept - A.O.B., H.S.; Design - A.O.B., B.Ş.; Supervision - H.A.; Materials - A.O.B.; Data Collection and/or Processing - Y.D.; Analysis and/ or Interpretation - A.O.B., B.Ş.; Literature Review - A.O.B., H.K., B.Ş.; Writer - A.O.B.; Critical Review - H.A., H.K., H.S. 


\section{Çıkar Çatışması}

Yazarlar herhangi bir çıkar çatışması bildirmemişlerdir.

Hakem değerlendirmesi: Dış bağımsız.

\section{Yazar Katkıları}

Fikir - A.O.B., H.S.; Tasarım - A.O.B., B.Ş.; Denetleme - H.A.; Malzemeler A.O.B.; Veri toplanması ve/veya işlemesi - Y.D.; Analiz ve/veya yorum - A.O.B., B.Ş.; Literatür taraması - A.O.B., H.K., B.Ş.; Yazıyı yazan - A.O.B.; Eleştirel İnceleme - H.A., H.K., H.S.

\section{References}

1. Dere E, Ozdikicioglu F, Tosunoglu H. Hepatotoxicity of Dinitro-O-Cresol in Rats (Rattus norvegicus), Acta Vet (Beograd) 2007; 57: 497-507. [CrossRef]

2. Lu YQ, Jiang JK, Huang WD. Clinical features and treatment in patients with acute 2,4-dinitrophenol poisoning. J Zhejian Univ-Sci B 2011; 12: 189-92. [CrossRef]
3. National Research Council. Drinking Water and Health. Vol. 4. Washington. National Academy Press; 1982.p.203.

4. Bains France. World Health Organization/International Programme on Chemical Safety; Environmental Health Criteria 220 Dinitro-ortho-cresol. 2000.p.1-4.

5. Harvey DG, Bidstrup PL, Bonnell JA. Poisoning by dinitro-ortho-cresol; some observations on the effects of dinitro-ortho-cresol administered by mouth to human volunteers. Br Med J 1951; 2: 13-6. [CrossRef]

6. Ray S, Peters CA. Changes in microbiological metabolism under chemical stress. Chemosphere 2008; 71: 474-83. [CrossRef]

7. Bartlett J, Brunner M, Gough K. Deliberate poisoning with dinitrophenol (DNP): an unlicensed weight loss pill. Emerg Med J 2010; 27: 159-60. [CrossRef]

8. Tewari A, Ali T, O'Donnell J, Butt MS. Weight loss and 2,4-dinitrophenol poisoning. Br J Anaesth 2009; 102: 566-7. [CrossRef]

9. Brown, Michael A, Robert L. Chessin. Toxicological profile for dinitrocresols. Research Triangle Inst., Durham, NC (United States), 1995.p.31.

10. Gosselin Robert E., Roger P. Smith, and Harold C. Hodge. Clinical toxicology of commercial products. 5th ed. Baltimore Williams \& Wilkins, 1984..p.157. 